\title{
From ISET to InDRE. IV. Institute of Epidemiological Diagnosis and Reference: new orientation, 1990-2012
}

\author{
María del Carmen Guzmán-Bracho, ${ }^{1}$ Jorge A. Ramírez-Hernández, ${ }^{2 *}$ Martha E. Rodríguez-Pérez, ${ }^{3}$ \\ Carlos Viesca-Treviño ${ }^{3}$ and José A. Díaz-Quiñonez ${ }^{2}$ \\ 'Institute of Epidemiological Diagnosis and Reference "Dr. Manuel Martínez Báez"; ${ }^{2}$ Universidad Nacional Autónoma de México, Faculty of Medicine, \\ Division of Postgraduate Studies; ${ }^{3}$ Universidad Nacional Autónoma de México, Faculty of Medicine, Department of History and Philosophy of \\ Medicine. Mexico City, Mexico
}

\begin{abstract}
From 1990 to 2012, the Sanitary and Tropical Diseases Institute experienced the most important changes. In 1989, its name and orientation were modified to become the National Institute of Epidemiological Diagnosis and Reference. Shortly before, it had been formalized as the apex of the National Network of Public Health Laboratories and had incorporated laboratories for preventive programs such as exfoliative cytology and rabies, malaria and tuberculosis diagnosis; subsequently, it would incorporate other networks that emerged as part of the response to major epidemic outbreaks and to the new epidemiological outlook. In this period, 27 priority diagnostic algorithms were defined, organized in 18 networks, some of which began to collaborate with global networks. In 2001, the Institute started working with pathogens related to bioterrorism. By then, space restrictions of the headquarter's building were evident; in 2008, starting the construction of new facilities was decided. The Institute and its diagnostic networks constitute a milestone in Latin American public health of the $21^{15 t}$ century.
\end{abstract}

KEY WORDS: Sanitary and Tropical Diseases Institute. Institute of Epidemiological Diagnosis and Reference. History of medicine.

\section{Desde el ISET al InDRE. IV. Instituto de Diagnóstico y Referencia Epidemiológicos: nueva orientación 1990-2012}

\section{Resumen}

De 1990 a 2012, el Instituto de Salubridad y Enfermedades Tropicales experimentó los cambios más importantes desde su origen. En 1989 modificó su nombre y orientación a Instituto Nacional de Diagnóstico y Referencia Epidemiológicos. Poco antes se había formalizado como cúspide de la organización piramidal denominada Red Nacional de Laboratorios en Salud Pública y había incorporado los laboratorios de programas preventivos como el de citología exfoliativa y los de diagnóstico de rabia, paludismo, tuberculosis; posteriormente incorporaría otras redes que surgieron como parte de la respuesta a brotes epidémicos importantes (cólera, VIH-sida, sarampión, influenza) y al nuevo panorama epidemiológico (dengue, Chagas, rotavirus). En este periodo se definieron 27 algoritmos diagnósticos prioritarios organizados en 18 redes, algunas de las cuales comenzaron a colaborar con redes globales. En 2001, en el Instituto se empezó a trabajar con patógenos relacionados con el bioterrorismo. Para entonces, las severas restricciones de espacio del edificio construido en 1935 fueron evidentes; en 2008, las autoridades decidieron iniciar el diseño y construcción de las nuevas instalaciones. En conjunto, el InDRE y sus redes diagnósticas constituyen un hito en la salud pública latinoamericana del siglo XXI.

PALABRAS CLAVE: Instituto de Salubridad y Enfermedades Tropicales. Instituto de Diagnóstico y Referencia Epidemiológicos. Historia de la medicina.

Correspondence:

*Jorge A. Ramírez-Hernández

E-mail: jorgealejandrorh@ @otmail.com
Date of reception: 01-10-2019

Date of acceptance: 03-01-2020

DOI: 10.24875/GMM.M20000353
Gac Med Mex. 2020;156:124-131

Contents available at PubMed

www.gacetamedicademexico.com

0016-3813/@ 2020 Academia Nacional de Medicina de México, A.C.. Published by Permanyer. This is an open access article under the CC BY-NC-ND license (http://creativecommons.org/licenses/by-nc-nd/4.0/). 


\section{Introduction}

This article covers the 1990-2012 period of the Sanitary and Tropical Diseases Institute (ISET - Instituto de Salubridad y Enfermedades Tropicales), which was transformed into the National Institute of Epidemiological Diagnosis and Reference. The name was changed during the first quarter of 1989 and the collaboration between epidemiology and preventive programs was strengthened through the National Network of Public Health Laboratories (RNLSP - Red Nacional de Laboratorios de Salud Pública), which started operating at ISET in $19855^{1-3}$ An interaction of InDRE with international reference laboratories and global diagnostic networks was developed. The RNLSP also participated in the National Public Health Laboratory (now the Commission for Analytical Control and Coverage Broadening) as a reference for health surveillance of dairy, water and food. ${ }^{4}$

In 1997 and 2010, INDRE and RNLSP obtained regulatory support. ${ }^{5,6}$ In 2000, as a result of the Law of National Health Institutes and without altering its new orientation, the term "National" was suppressed from the name of the Institute to become the Institute of Epidemiological Diagnosis and Reference (InDRE - Instituto de Diagnóstico y Referencia Epidemiológicos).? Only this denomination will be used.

During the study period, InDRE assumed the responsibility as a reference laboratory based on World Health Organization criteria: a specialized government laboratory that analyzes in depth the received samples; it advises, prepares, standardizes or evaluates diagnostic reagents; it issues guidelines for the operation of other laboratories, trains, conducts research and maintains relations with similar international centers. ${ }^{8}$

\section{National Seroepidemiological Survey, a successfully overcome challenge}

The National Seroepidemiological Survey forced the ISET to develop infrastructure and capacity to store, distribute and process half a million sera with their epidemiological information. The procedures were carried out with standard methods, under the control of international reference laboratories. ${ }^{9}$ The results, published in 1992, established the baseline of these conditions in Mexico (Table 1).

\section{The international situation}

The epidemiological transition and the new global challenges positioned the public health laboratory.
Global initiatives such as the Rio Declaration on Environment and Development (1992) were carried out in the 1990s. The World Bank presented Investing in health, a report whose objective was to help improve the efficiency of the sector in low and middle-income countries (1993). The United Nations Millennium Goals initiative (1995) identified HIV/AIDS, tuberculosis, Chagas disease and malaria as priorities. Soon after, the World Health Organization made a balance of the global epidemiological situation, still characterized by a high mortality attributable to infectious diseases. By the end of the $20^{\text {th }}$ century, it recognized the importance of chronic degenerative diseases and developed the Framework Convention for Tobacco Control. In turn, the World Heart Federation called the attention to the increase in cardiovascular conditions in countries of Latin America and Eastern Europe. In 2002, the World Health Organization launched the Global Strategy on Diet, Physical Activity and Health. In that year, the Global Fund to Fight HIV/AIDS, Tuberculosis and Malaria emerged; some resources were to be assigned to the InDRE.

\section{The RNLSP for epidemiological diagnosis. Organization and integration process}

\section{Adolfo Pérez Miravete wrote:}

[In 1985]... the role the institution could play in the new organization of the Ministry was reviewed, and assigning it a new orientation in order to fulfill some perceived needs in epidemiological services was decided, particularly as an infrastructure for transmissible diseases surveillance services The organization of the National Network of Health Laboratories [sic] also required a national institution at the top of the pyramid organization.

With funds from the United Nations Program for Development, ${ }^{10}$ between 1985 and 1989, the RNLSP responsibilities were reorganized, remodeled and strengthened.11 The RNLSP organization is shown in Figure 1, where the vertical lines of the front face of the pyramid represent laboratory networks for mandatory diagnoses for all 32 public health state laboratories (LESP - Laboratorios Estatales de Salud Pública). The lateral face shows the diagnoses not organized by networks or mandatory that are carried out at InDRE with support from other levels. In the diagram, support and administrative processes are represented by horizontal lines. When they cross the technical procedures (vertical lines) they produce a grid with hundreds of checkpoints.

By 1992, the RNLSP was already structured in three levels: the federal level in charge of InDRE, the state 
Table 1. National Seroepidemiological Survey. Diagnoses made at ISET from 1987 to 1989

\begin{tabular}{|l|l|r|r|}
\hline Diagnosis & $\begin{array}{l}\text { Tests (verified by international reference } \\
\text { laboratory) }\end{array}$ & $\begin{array}{c}\text { Number of samples* (age in years } \\
\text { of the study population) }\end{array}$ & $\begin{array}{c}\text { National prevalence } \\
\text { Average (range) }\end{array}$ \\
\hline Brucellosis & Plaque microagglutination (FAO/WHO) & $66,982(1$ to 98$)$ & $3.42 \%(0.24-13.5)$ \\
\hline $\begin{array}{l}\text { Toxoplasmosis } \\
\text { Chagas disease }\end{array}$ & Indirect immunofluorescence (Canada) & $29,279(1$ to 98$)$ & $32.0 \%(17.1-66.5)$ \\
\hline Indirect hemagglutination Indirect & immunofluorescence (Argentina) & $66,678(1$ to 98$)$ & $1.6 \%(0.1-5.0)$ \\
\hline Whooples & Hemagglutination inhibition (Mexico) & $5,232(12$ to 59 months of age) & $76.2 \%(42.0-87.5)$ \\
\hline
\end{tabular}

*Serum samples obtained on field work, urban and rural areas. FAO=Food and Agriculture Organization, WHO=World Health Organization. Source: reference 9

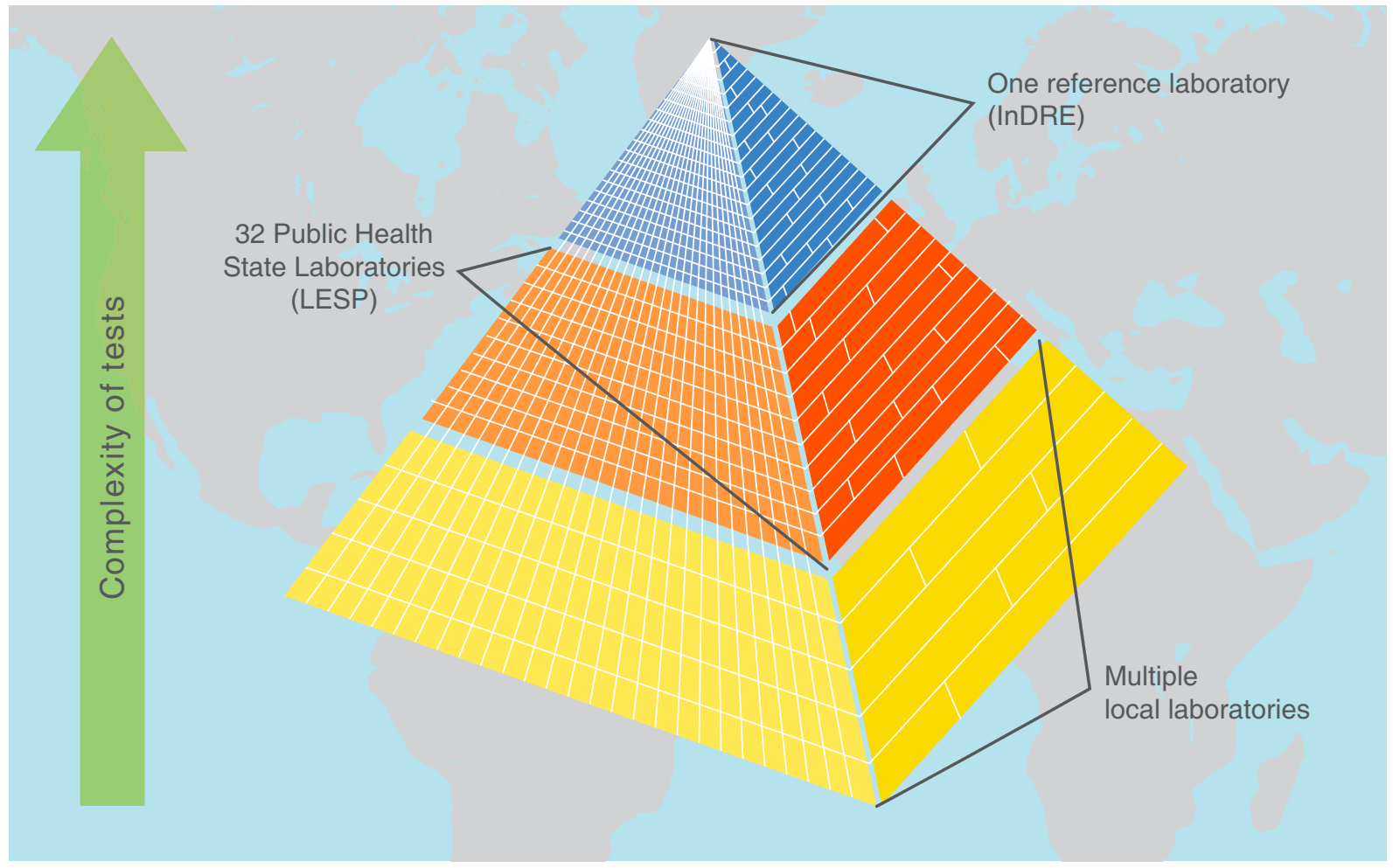

Figure 1. National Network of Public Health Laboratories pyramidal organization. Design: Francisco Meza Gordillo.

level with the LESPs and the local level. It was made up of almost 900 laboratories organized by diagnosis. By the end of the $20^{\text {th }}$ century, the RNLSP had 19 LESPs and four were under construction. ${ }^{12}$ Each group of laboratories that made the same mandatory diagnosis formed a specific network: the malaria network, tuberculosis network, etc. (Table 2).

The integration process followed by the RNLSP is interesting. From 1947 to 1984 , cytology diagnosis was performed in medical units in an assistance model..$^{13}$ In the 1970 s, the diagnosis of rabies was started in the Regional Laboratory of Virology, which later became the State Laboratory of Public Health in the State of Mexico (Nidia Aréchiga, personal communication). The laboratories for the malaria and tuberculosis programs worked separately. All joined the RNLSP in the 1980s (Table 2).

In the ensuing years, the malaria program received timely information from approximately 250 state and local microscopists (Sonia Galindo, personal communication) 
Table 2. National Network of Public Health Laboratories in 1992

\begin{tabular}{|c|c|c|c|c|}
\hline \multirow[t]{2}{*}{ Main function } & Central laboratory & State laboratories (n) & Local laboratories (n) & \multirow{2}{*}{$\begin{array}{l}\text { Participating } \\
\text { states (n) }\end{array}$} \\
\hline & Coordination and reference & Diagnosis and liaison & Diagnosis and screening & \\
\hline \multicolumn{5}{|l|}{ Diagnosis } \\
\hline Malaria & InDRE & 3 & 138 & 27 \\
\hline Tuberculosis and leprosy & InDRE & 10 & 474 & 32 \\
\hline Cervical cancer & InDRE & 2 & 40 & 16 \\
\hline Rabies & InDRE & 10 & 6 & 13 \\
\hline HIV/AIDS & InDRE & 6 LESP 17 CETS & 86 & 32 \\
\hline Cholera & InDRE & 16 & 73 & 31 \\
\hline Histocompatibility for transplants & InDRE & 1 & 23 & 9 \\
\hline
\end{tabular}

LESP (Laboratorio Estatal de Salud Pública) = Public Health State Laboratory, CETS (Centro Estatal de la Transfusión Sanguínea) = State Center of Blood Transfusion,

InDRE (Instituto de Diagnóstico y Referencia Epidemiológicos $)=$ National Institute of Epidemiological Diagnosis and Reference.

Source: Valdespino-Gómez JL. Informe técnico. Instituto Nacional de Diagnóstico y Referencia Epidemiológicos Dr. Manuel Martínez Báez, 1992-1993.

and from the entomology network, which also reinforced the surveillance of other vector-borne diseases. The tuberculosis program was supported by 31 LESPs and more than 700 local laboratories (Susana Balandrano, personal communication).

Another mechanism was the creation of networks in response to some conditions: the National HIV Network in 1986, the National Cholera Network in $1991^{14}$ and the Acute Respiratory Bacterial Infections Network in 2002 (Luis Ángel Sapian López and Isabel Moreno-Camilli, personal communication) (Table 2).

The networks were constantly evolving. Two examples: the diagnosis of exanthematic febrile disease included measles, rubella and dengue; the relevance of the latter motivated the creation of a specific network for dengue, which was expanded towards other arboviroses existing in Mexico or at risk of being introduced. Since 2009, the Network of Influenza and other Respiratory Viruses employed molecular methodologies at the LESPs and five laboratories that support epidemiological surveillance, which belong to different health institutions: Mexican Institute of Social Security, Institute of Social Security and Services for State Workers, General Hospital, National Institute of Medical Sciences and Nutrition and National Institute of Respiratory Diseases (Table 3).

The close monitoring of the performance of each LESP and the implementation of quality and biosafety management systems since 2002 (Celia González Bonilla and Lucía Hernández, personal communication) provided a framework of opportunity and reliability to the development of the RNLSP. ${ }^{15}$

In order to harmonize laboratory work with epidemiology, 27 priority diagnostic algorithms were defined, organized in 18 diagnostic networks, where all LESPs had to participate (Tere Martín Escobar, personal communication) (Table 3).
In the 1990s, at InDRE there was intense production of reagents and supplies that ensured diagnosis in the LESPs. Methodologies were introduced for large-scale seroepidemiological studies (Herlinda García Lozano, personal communication), in addition to molecular techniques to identify and characterize agents,,$^{16}$ as well as evaluation of the applicability of available commercial tests in the Mexican population (Roberto Vázquez Campuzano personal communication), which supported the anticipatory nature of surveillance. ${ }^{17}$

The InDRE implemented more than 300 algorithms of its own, including those for polio, mycosis, cysticercosis, free-living amoebas and pathogens involved in bioterrorism, as well as procedures to determine resistance to antiviral and antibacterial drugs and for the production of biological reagents.

\section{Flow of samples and information. Chain of custody and biosafety}

The pulse and capillarity of the pyramidal organization, unnoticed by the external user, are the result of the efforts of thousands of workers who mobilize clinical-epidemiological information with samples (human tissue and fluid, the pathogen itself, entomological specimen or genetic material), which are considered of high epidemiological value. Each sample is taken, identified, preserved, packed, transported from any location to its place of processing and final safekeeping (or disposal) in a network laboratory. This dynamic process has two elements: the care of the sample with its associated information (chain of custody) and the protection of professionals, population and environment (biosafety).

The biological materials protected in sample banks, some preserved since eight decades ago, are an invaluable heritage for research and reference. 
Gaceta Médica de México. 2020;156

Table 3. National Network of Public Health Laboratories

\begin{tabular}{|c|c|c|c|c|}
\hline \multicolumn{2}{|c|}{ Diagnostic algorithm* } & \multirow{2}{*}{$\begin{array}{l}\text { Conditions }^{\dagger} \\
\text { Cervical cancer }\end{array}$} & \multirow{2}{*}{$\begin{array}{l}\text { Start of the } \\
\text { network in Mexico } \\
\qquad 1947^{\ddagger}\end{array}$} & \multirow{2}{*}{$\begin{array}{l}\text { Start of diagnosis } \\
\text { at ISET-InDRE } \\
1985\end{array}$} \\
\hline 1 & Cervical cytology & & & \\
\hline 2 & Malaria & $\begin{array}{l}\text { Malaria by Plasmodium vivax (autochthonous), falciparum, } \\
\text { malariae and ovale (imported), acute Chagas disease, } \\
\text { cutaneous leishmaniasis }\end{array}$ & $1955^{\ddagger}$ & 1984 \\
\hline 3 & Tuberculosis & Pulmonary, extrapulmonary and drug-resistant tuberculosis & $1971^{\ddagger}$ & 1987 \\
\hline 6 & Rabies & Human rabies and in domestic and wild animals & 1972 & 1979 \\
\hline 4 & HIV/AIDS** & HIV/AIDS infection & 1986 & 1985 \\
\hline 5 & Entomology & $\begin{array}{l}\text { Diseases transmitted by vector mosquitoes, } \\
\text { hematophagous bedbugs, poisonous arthropods, } \\
\text { ectoparasites and other taxa }\end{array}$ & 1987 & 1939 \\
\hline 7 & $\begin{array}{l}\text { Acute bacterial diarrheal } \\
\text { disease }\end{array}$ & $\begin{array}{l}\text { Cholera, outbreaks of Vibrio parahemolyticus and } \\
\text { Escherichia coli gastroenteritis, salmonellosis, shigellosis }\end{array}$ & 1991 & 1939 \\
\hline 8 & Brucellosis & Human brucellosis & 1992 & 1939 \\
\hline 9 & $\begin{array}{l}\text { Febrile exanthematous } \\
\text { illness }\end{array}$ & $\begin{array}{l}\text { Measles, rubella, congenital rubella, differential } \\
\text { diagnosis for mumps, chicken pox, infections } \\
\text { by Epstein-Barr virus, parvovirus B19 and other } \\
\text { exanthematous viruses }\end{array}$ & 1992 & 1972 \\
\hline 10 & Chagas disease & Acute, congenital or chronic Chagas disease & 1994 & 1939 \\
\hline 11 & Leishmaniasis & $\begin{array}{l}\text { Cutaneous, mucocutaneous, diffuse cutaneous and visceral } \\
\text { leishmaniasis }\end{array}$ & 1994 & 1939 \\
\hline 12 & Whooping cough & Whooping cough and pertussis-like syndrome & 1995 & 1942 \\
\hline 13 & $\begin{array}{l}\text { Dengue and other } \\
\text { arboviroses }\end{array}$ & $\begin{array}{l}\text { Dengue, Zika, Chikungunya, West Nile virus disease, yellow } \\
\text { fever }\end{array}$ & 1995 & 1978 \\
\hline 14 & $\begin{array}{l}\text { Rotavirus and other } \\
\text { enteroviruses }\end{array}$ & $\begin{array}{l}\text { Gastroenteritis caused by rotavirus, norovirus, sapovirus, } \\
\text { astrovirus, enteric adenoviruses } 40 \text { and } 41\end{array}$ & 1996 & 1994 \\
\hline 15 & $\begin{array}{l}\text { Influenza and other } \\
\text { respiratory viruses }\end{array}$ & $\begin{array}{l}\text { Influenza and infections caused by respiratory syncytial } \\
\text { virus, human metapneumovirus, parainfluenza 1, 2, } 3 \text { and } 4 \\
\text { viruses; coronavirus 229E, OC43, HKU1, NL63, adenovirus, } \\
\text { rhinovirus, enterovirus and bocavirus }\end{array}$ & 1997 & 1951 \\
\hline 16 & Leptospira & Human leptospirosis & 1997 & 1993 \\
\hline 17 & Hepatitis & Hepatitis A, B, C & 1998 & 1973 \\
\hline 18 & $\begin{array}{l}\text { Acute bacterial respiratory } \\
\text { infections }\end{array}$ & $\begin{array}{l}\text { Severe acute respiratory infections and invasive infections } \\
\text { caused by Streptococcus pneumoniae, Neisseria } \\
\text { meningitidis and Haemophilus influenzae }\end{array}$ & 2002 & 1980 \\
\hline 19 & Rickettsiosis & $\begin{array}{l}\text { Spotted Rocky Mountain Fever, epidemic typhus, murine or } \\
\text { endemic typhus }\end{array}$ & 2016 & 1973 \\
\hline 20 & $\begin{array}{l}\text { Sexually transmitted } \\
\text { infections } \$\end{array}$ & $\begin{array}{l}\text { Syphilis, genital herpes, lymphogranuloma venereum, } \\
\text { gonococcal urethritis and cervicitis, non-gonococcal } \\
\text { urethritis, mucopurulent cervicitis, vaginal discharge, pelvic } \\
\text { inflammatory disease, human papillomavirus }\end{array}$ & 2016 & 1974 \\
\hline
\end{tabular}

*2019 valid names are used. Each diagnostic algorithm constitutes a laboratory network.

tThose indicated in diagnostic algorithms valid in 2019 are mentioned.

ŁLaboratories coordinated by preventive and control programs. The Cervical Cancer Quality Control Laboratory started operating until 1985.

${ }^{*}$ In the 1970s, the reference laboratory of the Eliseo Ramírez Center for sexually transmitted infections was integrated to the ISET. The network started as Network for HIV and other Sexually-Transmitted Diseases.

${ }^{+}$Started operating in the Febrile Exanthematous IIIness Network.

¥¥Operated from 1985 to 2016 within the Network for HIV and other Sexually-Transmitted Disease. 


\section{InDRE response to infectious disease events}

Some epidemic events (such as cholera, HIV/AIDS and dengue) motivated the creation of networks. It is important to highlight the special response given to measles and the influenza pandemic. ${ }^{18-22}$

The management of the cholera outbreak in 1991 was emblematic for the training the InDRE professionals cascaded to the LESPs, which reproduced it in 239 local, public and private laboratories. ${ }^{23}$ The InDRE carried out the genotyping and antimicrobial susceptibility testing, developed and sent biological reagents to the LESPs, supervised and evaluated screening in the states. ${ }^{24}$

This successful technology transfer model would be used to deal with outbreaks and health emergencies by dengue, cholera and leptospirosis in hydrometeorological events, even to support Central American countries.

In 2001, anthrax diagnosis was established as a preparation for potential bioterrorism actions; evidence of low risk for the Mexican population was provided (Hiram Olivera Díaz, personal communication). Biological risk management was strengthened in the RNLSP.

Influenza $A$ (H1N1)pdm arrived to Mexico when the classical methods of virology and molecular biology were sufficiently developed to carry out confirmation, subtyping, isolation, sequencing, bioinformatics analysis and antiviral resistance surveillance (Ernesto Ramírez González and Irma López, personal communication). InDRE deployed a rapid response -initially 24 hours a day, every day of the week- and transferred molecular techniques in real time that expedited the response and population impact assessment. The special response to the pandemic (Command System for Incidents) included the entire RNLSP. ${ }^{25,26}$

\section{Bioterrorism, early alert and containment}

Since 1999, InDRE officially participates in the Convention on the Prohibition of the Development, Production and Stockpiling of Bacteriological and Toxin Weapons and on their Destruction (Irma Hernández-Monroy, personal communication).

In 2001, in addition to the diagnosis of West Nile virus, SARS Co-V and anthrax, the diagnostic capacity for Francisella tularensis, Yersinia pestis, variola virus and botulinum toxin was added to the Institute, ${ }^{27-29}$ in view of the risk of deliberate release. ${ }^{30}$
That same year, Mexico joined the Global Health and Safety Initiative. In the network of laboratories of this initiative, InDRE participates in the G7+Mexico, which allowed to maintain the capability to address threats to national health security.

In 2010, InDRE's effort was recognized in the United States, and it was included in the Laboratory Response Network (LRN), a select network of laboratories where the Centers for Disease Control and Prevention (CDC)), the Department of Health and Human Services (DHHS), the US Department of Agriculture (USDA), the Food and Drug Administration (FDA), the Federal Bureau of Investigation (FBI) and other USA agencies do participate.

Only Canada, Australia, the United Kingdom and Mexico are LRN member countries and maintain standard laboratory procedures to respond to bioterrorism events, emerging infectious diseases, chemical terrorism and other public health contingencies.

\section{Bank of reference biological material}

Biological materials under institutional protection (strains, human samples, entomological material, genetic sequences) and others acquired from international banks (standards, controls) are essential to achieve high quality in the performance of a reference laboratory.

An example is the Collection of Arthropods of Medical Importance, started in 1938 and cataloged since 1987. The continuous incorporation of specimens has enabled having the largest collection in Latin America (Sergio Ibáñez, personal communication).

The registration, classification and packaging of the biological material to be brought to the new InDRE headquarters was carried out under strict conditions of biosafety and biocustody, in compliance with national and international regulations.

\section{The construction of the new InDRE facilities}

In 2007, given the obsolescence and insecurity of the facilities for workers and its immediate surroundings, the health authorities recognized the need for a new and modern infrastructure for the InDRE. The document Bases for the design of InDRE new facilities, of 2008, noted the conditions of the facilities built in 1935.

The executive project for the laboratory building was developed by an international, specialized company, with a contemporary design and building materials and systems that would optimize operation and maintenance. ${ }^{31}$ 


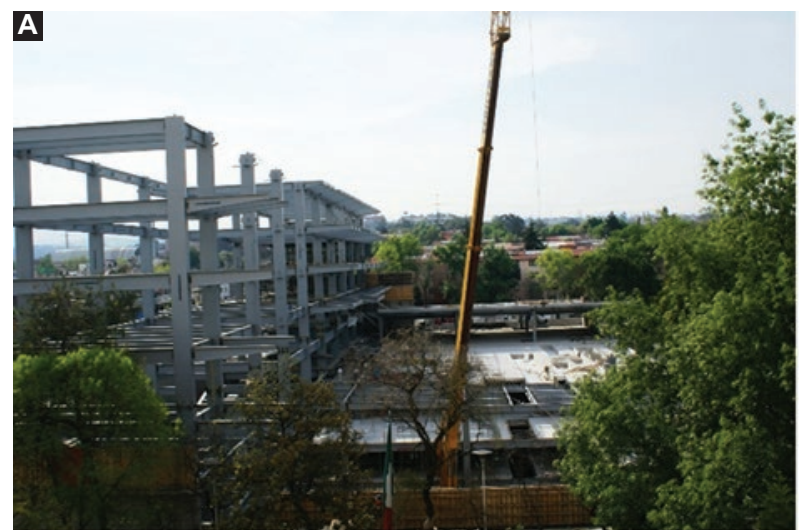

2010

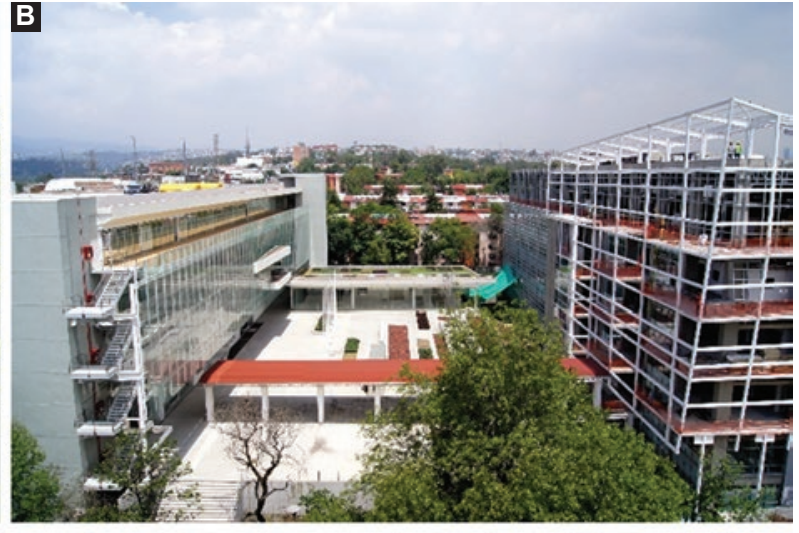

2011

Figure 2. Construction of the new InDRE facilities at Lomas de Plateros, Mexico City. A: 2010, photograph by Rita Flores León. B: 2011, photograph by Amelia Patiño González.

Table 4. Directors of the Institute of Epidemiological Diagnosis and Reference, 1990-2019

\begin{tabular}{|l|c|}
\hline Director & Period \\
\hline José Luis Valdespino Gómez & $1990-1994$ \\
\hline Ana Flisser Steinbruch & $1995-2000$ \\
\hline Elsa Josefina Sarti Gutiérrez & $2001-2003$ \\
\hline Ignacio Federico Villaseñor Ruiz & $2003-2007$ \\
\hline Celia Mercedes Alpuche Aranda & $2007-2012$ \\
\hline José Alberto Díaz Quiñonez & $2012-2019$ \\
\hline
\end{tabular}

The administrative building was designed in the tradition of the Mexican architectural school (Fig. 2). Total constructed area, almost $17,000 \mathrm{~m}^{2}$ of laboratories would boost the fulfillment of the InDRE mission in the national and international spheres (Smith Carter-ICEMEX, InDRE. Diseño esquemático/bases de diseño, 2008).

\section{Discussion}

In 1989, ISET became the InDRE and dedicated its activity to epidemiological surveillance and referral. The name change of the institution, from ISET to InDRE was a gradual, discreet process, without ceremony, during the first quarter of that year (Alejandro Escobar, personal communication).

In 1985, the ISET had already been appointed head of the National Network of Public Health Laboratories, which obtained legal support in 1997 and 2010. These decisions helped to address the HIV/AIDS, cholera, dengue, measles and influenza epidemic events, which required a special response from the RNLSP.

By the end of this crucial institutional period, with the RNLSP in operation but with new epidemiological challenges such as the influenza pandemic, it became clear that the InDRE infrastructure was inappropriate. The 1935 art deco building was replaced by state-of-the-art architectural installations, to consolidate the intense national work and boost global participation. The list of directors for the 1990-2019 period is presented in Table 4.

InDRE and its diagnostic networks constitute a milestone for Latin American public health of the $21^{\text {st }}$ century.

\section{Acknowledgements}

To the authorities and personnel of the Historical Archive of the Ministry of Health, for selflessly sharing their knowledge and for their valuable guidance in the review of files.

\section{References}

1. Ramírez-Hernández JA, Guzmán-Bracho C, Díaz-Quiñonez JA. Desde el ISET al InDRE. I. Instituto de Salubridad y Enfermedades Tropicales: génesis y primeros años, 1934-1940. Gac Med Mex. 2019;155:322-327.

2. Ramírez-Hernández JA, Guzmán-Bracho MC, Viesca-Treviño C, Díaz-Quiñonez JA. Desde el ISET al InDRE. II. Instituto de Salubridad y Enfermedades Tropicales: madurez y consolidación, 1940-1964. Gac Med Mex. 2019;155:398-405.

3. Ramírez-Hernández JA, Guzmán-Bracho C, Rodríguez-Pérez ME, Viesca-Treviño C, Díaz-Quiñonez JA. Desde el ISET al InDRE. III. Instituto de Salubridad y Enfermedades Tropicales: crisis y renovación, 19651989. Gac Med Mex. 2019;155:641-646.

4. Del Río-Zolezzi A, Valdespino-Gómez JL, García-García ML, Giono-Cerezo S, Escobar-Gutiérrez A. La Red Nacional de Laboratorios de Salud Pública en México. Higiene. 1994;2:101-120.

5. Reglamento Interior de la Secretaría de Salud. México: Diario Oficial de la Federación 2001 Jul 5.

6. Decreto que reforma, adiciona y deroga diversas disposiciones del Reglamento Interior de la Secretaría de Salud. México: Diario Oficial de la Federación 2010 Feb 2. 
7. Flisser-Steinbruch A. Editorial. Salud Publica Mex. 2000;42:482-483.

8. Planificación, organización y administración de un servicio nacional de salud pública. Tercer informe del Comité de Expertos en Servicios de Laboratorio de Salud Pública. Organización Mundial de la Salud; 1962.

9. Sepúlveda-Amor J, Tapia-Conyer R. Encuesta Nacional Seroepidemiológica. Número Especial. Salud Publica Mexico. 1992;34:119-254.

10. Pérez-Miravete, A. Quincuagésimo aniversario del Instituto de Salubridad y Enfermedades Tropicales. Archivo familia Pérez de la Mora.

11. Sepúlveda-Amor J. La vigilancia en salud pública y las Redes Nacionales de Laboratorios. Higiene. 1994;2:95-100.

12. Flisser A, Velasco-Villa A, Martínez-Campos C, González-Domínguez F, Briseño-García B, García-Suárez, et al. Infectious diseases in Mexico. A survey from 1995-2000. Arch Med Res. 2002;33:343-350.

13. Carrillo AM. Entre el 'sano temor' y el 'miedo razonable': la Campaña Nacional Contra el Cáncer en México. Historia Ciencias Saude. 2010; 17:89-107.

14. Valdespino-Gómez JL. Instituto Nacional de Diagnóstico y Referencia Epidemiológicos Dr. Manuel Martínez Báez 1992-1993. México: Instituto Nacional de Diagnóstico y Referencia Epidemiológicos "Dr. Manuel Martínez Báez"; 1992

15. Secretaría de Salud [sitio web]. Red Nacional de Laboratorios de Salud Pública/Instituto de Diagnóstico y Referencia Epidemiológicos. Caminando a la Excelencia. 2003.

16. Escobar-Gutiérrez A, Flisser A. La trascendencia de la metodología molecular en el diagnóstico. Gac Med Mex. 1997;133:105-110.

17. Editorial. Higiene. 1994;2:93-94.

18. Lineamientos para la vigilancia por laboratorio de la infección por el virus de la inmunodeficiencia humana (VIH). México: Instituto de Diagnóstico y Referencia Epidemiológicos "Dr. Manuel Martínez Báez"/Secretaría de Salud; 2017.

19. Lineamientos para la vigilancia por laboratorio de la enfermedad diarreica aguda bacteriana. México: Instituto de Diagnóstico y Referencia Epidemiológicos “Dr. Manuel Martínez Báez"/Secretaría de Salud; 2017.
20. Lineamientos para la vigilancia por laboratorio de la enfermedad febril exantemática. México: Instituto de Diagnóstico y Referencia Epidemiológicos "Dr. Manuel Martínez Báez"/Secretaría de Salud; 2018.

21. Lineamientos para la vigilancia por laboratorio de dengue y otras arbovirosis. México: Instituto de Diagnóstico y Referencia Epidemiológicos "Dr. Manuel Martínez Báez"/Secretaría de Salud; 2017.

22. Lineamientos para la vigilancia por laboratorio de la influenza y otros virus respiratorios. México: Instituto de Diagnóstico y Referencia Epidemiológicos "Dr. Manuel Martínez Báez"/Secretaría de Salud; 2017.

23. Sepúlveda J, Valdespino JL, García-García L. Cholera in Mexico: the paradoxical benefits of the last pandemic. Int J Infect Dis. 2006; 10:4-13.

24. Giono-Cerezo S, Rodríguez-Ángeles MG, Gutiérrez-Cogco L, Valdespino-Gómez JL. Caracterización fenotípica y genotípica de Vibrio cholerae O1. Rev Latinoam Microbiol. 1994;36:243-251.

25. Díaz-Quiñonez JA, Alpuche-Aranda CM. Métodos diagnósticos de influenza por laboratorio. En: Córdova-Villalobos, Valdespino-Gómez, Ponce-de León. La epidemia de influenza A/H1N1 en México. México: Editorial Médica Panamericana; 2010.

26. Díaz-Quiñonez JA. Libro blanco 2006-2012. México: Instituto de Diagnóstico y Referencia Epidemiológicos; 2012

27. Valdespino-Gómez JL, García-García ML. El A, B, C, sobre ántrax, para personal de salud. Salud Publica Mex. 2001;43:604-613.

28. Lineamientos para la vigilancia, prevención y control de enfermedades asociadas a riesgos biológicos. México: Secretaría de Salud; 2001.

29. Sarti E, Moreno-Galván M, Rodríguez-Ángeles G, Viveros G, Flores-León R, Tapia-Conyer R. Molecular characterization of anthrax in positive powders: a Mexican experience. J Clin Microbiol. 2003;41:4909.

30. Franco-Paredes C, Lammoglia L, Santos-Preciado JI. Perspectiva histórica de la viruela en México: aparición, eliminación y riesgo de reaparición por bioterrorismo. Gac Med Mex. 2004;140:321-327.

31. HKS Arquitectos. Laboratorios para el Instituto de Diagnóstico y Referencia Epidemiológicos (InDRE). Rev arquiTK. 2013;12:74-77. 